\title{
Gap junctional communication promotes apoptosis in a connexin-type-dependent manner
}

\author{
P Kameritsch ${ }^{\star, 1}$, N Khandoga ${ }^{1}$, U Pohl ${ }^{1,2,3}$ and K Pogoda ${ }^{1}$
}

Gap junctions (GJs) have been described to modulate cell death and survival. It still remains unclear whether this effect requires functional GJ channels or depends on channel-independent effects of connexins (Cx), the constituents of GJs. Therefore, we analysed the apoptotic response to streptonigrin (SN, intrinsic apoptotic pathway) or to $\alpha$-Fas (extrinsic apoptotic pathway) in HeLa cells expressing Cx43 as compared with empty vector-transfected (CTL) cells. Apoptosis assessed by annexin V-fluorescein isothiocyanate/propidium iodide staining was significantly higher in HeLa-Cx43 compared with HeLa-CTL cells. Moreover, the cleavage of caspase-7 or Parp occurred earlier in HeLa-Cx43 than in HeLa-CTL cells. Comparative analysis of the effect of two further (endothelial) $\mathrm{Cx}$ (Cx37 and Cx40) on apoptosis revealed that apoptosis was highest in HeLa-Cx43 and lowest in HeLa-Cx37 cells, and correlated with the GJ permeability (assessed by spreading of a GJ-permeable dye and locally induced $\mathrm{Ca}^{2+}$ signals). Pharmacologic inhibition of GJ formation in HeLa-Cx43 cells reduced apoptosis significantly. The role of GJ communication was further analysed by the expression of truncated $\mathrm{Cx} 43$ proteins with and without channel-forming capacity. Activation of caspases was higher in cells expressing the channel-building part (HeLa-Cx43NT-GFP) than in cells expressing the channel-incompetent C-terminal part of Cx43 (HeLa-Cx43CT-GFP) only. A hemichannel-dependent release and, hence, paracrine effect of proapoptotic signals could be excluded since the addition of a peptide (Pep)-blocking Cx43-dependent hemichannels (but not GJs) did not reduce apoptosis in HeLa-Cx43 cells. Treatment with SN resulted in a significant higher increase of the intracellular free $\mathrm{Ca}^{2+}$ concentration in HeLa-Cx43 and HeLa-Cx43NT-GFP cells compared with HeLa-CTL or HeLa-Cx43CT-GFP cells, suggesting that $\mathrm{Ca}^{2+}$ or a $\mathrm{Ca}^{2+}$-releasing agent could play a signalling role. Blocking of inositol triphosphate receptors reduced the $\mathrm{SN}$-induced $\mathrm{Ca}^{2+}$ increase as well as the increase in apoptosis. Our observations suggest that $\mathrm{Cx} 43$ and $\mathrm{Cx} 40$ but not Cx37 promote apoptosis via gap junctional transfer of pro-apoptotic signals between cells.

Cell Death and Disease (2013) 4, e584; doi:10.1038/cddis.2013.105; published online 11 April 2013

Subject Category: Experimental Medicine

A growing body of evidence shows that connexins $(\mathrm{Cx})$ are able to modulate essential cellular processes such as proliferation, differentiation and migration. Likewise, survival and apoptosis have been shown to be partially $\mathrm{Cx}$-dependent processes. ${ }^{1-3}$ However, it remains unclear whether $\mathrm{Cx}$ exert their functions in a manner which is dependent on their ability to form gap junction (GJ) channels or whether channelindependent properties of $\mathrm{Cx}$ play a role such as that observed in cell migration and proliferation. ${ }^{4-7}$ This question is still controversially discussed. There are a few studies suggesting that $\mathrm{Cx}$, and in particular $\mathrm{Cx} 43$, have effects on cell death and survival by mechanisms independent of gap junctional communication. Most of these effects have been related to the potential role of hemichannels that may allow the passage of proapoptotic or survival factors from the intracellular to the extracellular space or vice versa. ${ }^{8-12}$ Alternatively, regulatory effects of $\mathrm{Cx}$ were found to play a role in pro- and antiapoptotic genes. ${ }^{1}$ DNA arrays of Cx43-null and wild-type mice indeed showed clear differences in gene expression. ${ }^{13}$ For example, in Cx43-expressing glioblastoma cells, a decreased expression of bcl-2 has been described, and a suppression of Src activity was observed in Cx43-expressing malignant mesothelioma cells. ${ }^{14,15}$ Moreover, the intracellular localisation of $\mathrm{Cx} 43$ at the mitochondrial ${ }^{16-19}$ or nuclear $^{20}$ membranes has been shown to have a role in this context. Other reports refer to a distinct role of gap junctional communication in promoting apoptosis. For example, experiments performed with heavy ions ${ }^{21}$ or cytochrome $C^{22,23}$ as inducers of apoptosis demonstrated cell death in untreated neighbouring cells, which points towards a role of GJs in modulating apoptosis. Not only death signals but also cell survival factors have been proposed to be transferred via GJs. ${ }^{24-26}$ However, in most cases, it has not been studied whether GJ channels or channel-independent effects were important. Thus, it remains unclear which of the two potential Cx-related pathways is quantitatively more important and whether the modulatory effect of $\mathrm{Cx}$ on apoptosis depends on the type of Cx expressed. It is also unclear which signals or small molecules, which are able to pass GJs, could be involved in promotion of apoptosis.

\footnotetext{
${ }^{1}$ Walter Brendel Centre of Experimental Medicine, Ludwig-Maximilians-Universität München and Munich University Hospital, Munich, Germany; ${ }^{2} \mathrm{DZHK}$ (German Centre for Cardiovascular Research), partner site Munich Heart Alliance, Munich, Germany and ${ }^{3}$ Munich Cluster for Systems Neurology (SyNergy), Munich, Germany ${ }^{*}$ Corresponding author: P Kameritsch, Walter Brendel Centre of Experimental Medicine, Ludwig-Maximilians-Universität München and Munich University Hospital, Marchioninistrasse 27, München 81377, Germany. Tel: + 4989 2180 76536; Fax: + 49892180 76532; E-mail: Kameritsch@Imu.de

Keywords: gap junction; connexin; apoptosis; streptonigrin; Fas; $\mathrm{Ca}^{2+} ; \mathrm{IP}_{3}$

Abbreviations: GJ, gap junction; Cx, connexin/s; NT, N-terminal part; CT, C-terminal part; SN, streptonigrin; $\mathrm{Ca}^{2+}{ }_{\text {i, }}$ intracellular free calcium; FITC, fluorescein isothiocyanate; $\mathrm{PI}$, propidium iodide; aa, amino acids; $\mathrm{IP}_{3}$, inositol triphosphate; $\alpha$, anti

Received 10.8.12; revised 31.1.13; accepted 21.2.13; Edited by Y Shi
} 
To clarify these questions, we studied apoptosis in Cx-transfected HeLa cells with no background expression of Cx in the wild-type state. Our results show that the Cx-dependent enhancement of apoptosis requires gap junctional communication and that this effect varies with the type of Cx expressed.

\section{Results}

Expression of $\mathbf{C x 4 3}$ enhances the rate of apoptosis. To examine the effect of $\mathrm{Cx} 43$ expression on apoptosis, we used HeLa cells stably transfected with $\mathrm{Cx} 43$ or $\mathrm{Cx}$-deficient empty vector-transfected HeLa cells (CTL) as controls. Apoptosis was either induced by streptonigrin (SN; intrinsic pathway) or $\alpha$-Fas (extrinsic receptor-stimulated pathway). Treatment with SN $(1,10 \mu \mathrm{M})$ or $\alpha$-Fas $(10,100 \mathrm{ng} / \mathrm{ml})$ lasted for $5 \mathrm{~h}$ and the rate of apoptosis was determined by annexin V-fluorescein isothiocyanate (FITC)/propidium iodide (PI) staining. Under both conditions, the apoptosis was significantly higher in HeLa-Cx43 cells compared with HeLa-CTL cells (Figure 1b). Likewise, treatment with SN $(10 \mu \mathrm{M})$ resulted in a higher and earlier increase of cleavage products of Parp (cl. Parp) and caspase-7 (cl. Cas7) when Cx43 was present (Figure 1c). Similarly, stimulation with $\alpha$-Fas $(100 \mathrm{ng} / \mathrm{ml})$ resulted in cleaved Parp and caspase-7 already after $2 \mathrm{~h}$ in HeLa-Cx43 cells, whereas in HeLa-CTL cells, it started only after $4 \mathrm{~h}$ (Figure 1c).

The Cx effect on apoptosis varies with the Cx type and correlates with gap junctional dye or calcium transfer. To elucidate the effect of other $\mathrm{Cx}$ proteins and their channel properties on the development of apoptosis, HeLa cells expressing either $\mathrm{Cx} 37$ or $\mathrm{Cx} 40$ or $\mathrm{C} \times 43$ were compared. The expression of the different $\mathrm{Cx}$ proteins was analysed by western blot (Figure 2a). Immunocytochemically, the cells showed the typical expression pattern with an increased localisation at cell-cell contacts (Figure 2b). Cx-deficient HeLa-CTL cells were used as controls. Apoptosis was induced with $\mathrm{SN}(1 \mu \mathrm{M}, 3 \mathrm{~h})$ and measured by annexin V-FITC/PI staining. The increase of apoptotic cells after stimulation with $\mathrm{SN}$ was lowest in HeLa-CTL cells and highest in Cx43-expressing cells (Figure 2c). The $\mathrm{SN}$-induced increase in apoptotic cells was significantly higher in Cx43-expressing cells compared with HeLa-Cx37 cells.

To figure out whether the differences in the increase of $\mathrm{SN}$-induced apoptotic cells were associated with different GJ channel permeabilities, we assessed cell coupling by intercellular spreading of a GJ-permeable fluorescent dye after injection of a single cell (Figure $2 \mathrm{~d}$ ). HeLa-CTL cells showed no ( $n$ stained cells, mean \pm S.E.M.: $0.1 \pm 0.1)$ and HeLa-Cx37 only little dye transfer $(2 \pm 1)$. In contrast, cell coupling of Cx40- and Cx43-expressing HeLa cells (Cx40: $9 \pm 1$; Cx43: $17 \pm 2$ ) was significantly elevated as compared with HeLaCTL cells. Thus, the highest number of stained neighbouring cells was observed in HeLa-Cx43 cells. In addition, we analysed the intercellular spreading of a $\mathrm{Ca}^{2+}$ signal after mechanical stimulation of a single cell. Again, the signal spread wider in HeLa-Cx43 cells compared with HeLa-Cx37 and HeLa-CTL cells ( $n$ cells with elevated $\mathrm{Ca}^{2+}$; mean \pm S.E.M. - Cx43: $21 \pm 3$; Cx37: $12 \pm 2$; CTL: $0 \pm 0 ; P<0.05$; two different cell cultures, $n=10-14)$.
We further investigated whether the treatment with SN has an influence on the gap junctional coupling. Dye transfer via GJs was measured in HeLa-Cx43 cells, the cell population with the highest amount of apoptosis. After treatment with SN for 1 or $3 \mathrm{~h}$, the cells were still able to form functional GJs, although the rate of coupling decreased over time ( $n$ stained cells; mean \pm S.E.M. - untreated cells: $17 \pm 2$; $1 \mu \mathrm{M} \mathrm{SN}$ for $1 \mathrm{~h}$ : $11 \pm 2 ; 1 \mu \mathrm{M}$ SN for $3 \mathrm{~h}: 6 \pm 1 ; n \geq 7$ in three different cell cultures).

Gap junctional communication is required for enhancement of apoptosis. The role of GJ communications for the enhanced apoptosis was firstly investigated by using the GJ blockers meclofenamic acid $(\mathrm{M} ; 100 \mu \mathrm{M})$ and heptanol $(\mathrm{H}, 0.25 \mathrm{mM})$. The amount of SN- or $\alpha$-Fas-induced apoptotic HeLa-Cx43 cells (mean \pm S.E.M. $-1 \mu \mathrm{M}$ SN: $15.5 \pm 4.7 \%$; $100 \mathrm{ng} / \mathrm{ml}$ Fas: $24.1 \pm 3.6 \%$ ) was significantly reduced under treatment with GJ blockers $(1 \mu \mathrm{M} \mathrm{SN}+\mathrm{MH}: 7.1 \pm 0.4 \%$; $100 \mathrm{ng} / \mathrm{ml}$ Fas $+\mathrm{MH}: 11.8 \pm 1.1 \%$; Figure 3). GJ blockers alone did not affect the basal rate of apoptosis (untreated cells: $6.4 \pm 0.6 \%$; cells treated with the GJ blockers only $\mathrm{MH}: 6.0 \pm 0.7 \%)$.

To further analyse whether an intact channel function between cells was necessary for the enhanced apoptosis in Cx43-expressing cells, we compared apoptosis in HeLa cells expressing the $\mathrm{N}$-terminal channel-building part of $\mathrm{Cx} 43$ (Cx43NT-GFP) with cells expressing the cytoplasmic C-terminal part (CT) of Cx43 (Cx43CT-GFP), which cannot form GJs or hemichannels but exerts channel-independent functions of Cx43. ${ }^{5}$ As controls, we used HeLa cells expressing full-length Cx43 (Cx43-GFP). To determine the rate of SN-induced apoptosis in these cells, the amount of activated caspases (caspase-1, -3, -4, -5, -6, -7, -8 and -9) was measured (binding of a red fluorescent-labelled inhibitor to active caspases), as the expression of GFP interfered with the annexin V-FITC/PI assay otherwise used. The fluorescence intensity (red fluorescence units (RFUs)), indicating activated caspases, was significantly higher in the channel-forming HeLa-Cx43-GFP (mean \pm S.E.M.: 21422 \pm 1494 ) and HeLa-Cx43NT-GFP cells $(22546 \pm 2031)$ as compared with the channel-incompetent HeLa-Cx43CT-GFP cells (14543 \pm 758; Figure 4).

Hemichannels are not involved in augmented apoptosis of Cx43-expressing cells. The potential release of proapoptotic signals via $\mathrm{Cx}$ hemichannels, which may act in a paracrine manner, was investigated by specific blockade of Cx43 hemichannels using an inhibitory Pep $(50 \mu \mathrm{M}),{ }^{27}$ which does not affect gap junctional communication (HeLa-Cx43 cells; $\mathrm{Ca}^{2+}$ spreading due to mechanical stimulation; untreated: $25 \pm 2$ cells; control peptide (ConPep): $28 \pm 3$ cells; Pep: $27 \pm 2$ cells; $n=9$ in three different cell culture wells). The amount of apoptosis of HeLa-Cx43 cells with SN $(10 \mu \mathrm{M})$ or $\alpha$-Fas $(100 \mathrm{ng} / \mathrm{ml})$ was not changed under treatment with the hemichannel-blocking Pep (SN + Pep; Fas + Pep; Figure 5a). Apoptosis of cells incubated with the inhibitory Pep alone was as low as that of untreated cells or of cells incubated with the ConPep (Figure 5a). The efficiency of the hemichannel-blocking Pep was tested by measuring the uptake of PI via hemichannels in HeLa-Cx43 cells. Both 

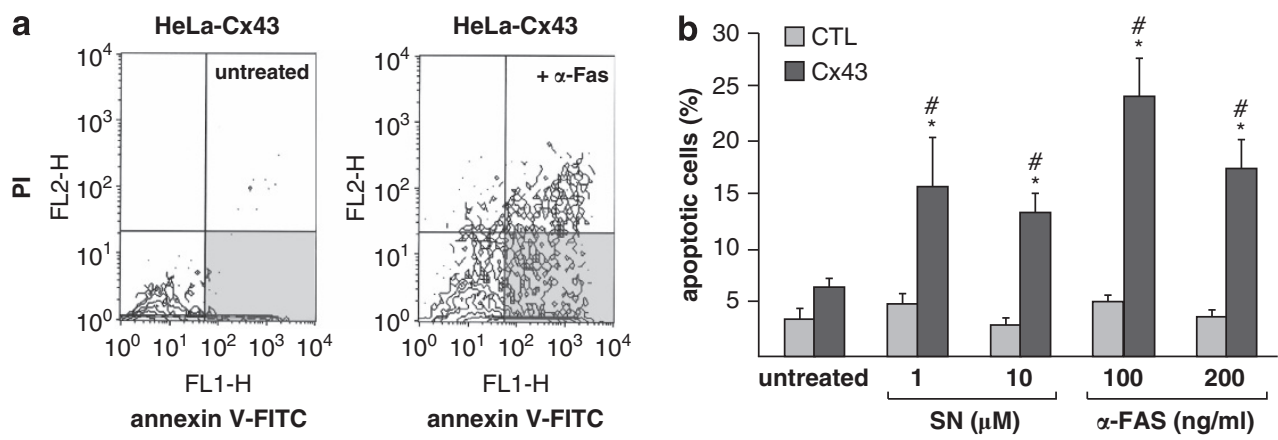

c
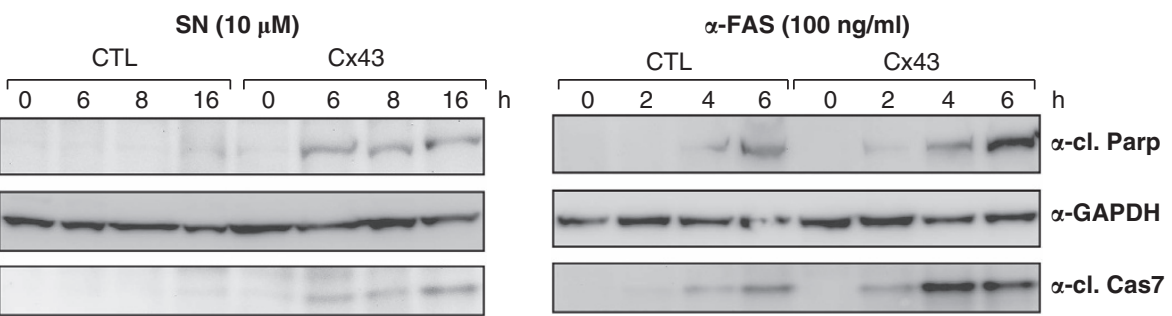

Figure 1 Cx43 expression enhances apoptosis of HeLa cells. (a) Representative contour plots of untreated and $\alpha$-Fas $(100 \mathrm{ng} / \mathrm{ml}, 5 \mathrm{~h})$-treated HeLa-Cx43 cells. The amount of apoptotic cells was determined by annexin V-FITC/PI staining and is displayed in the lower right quadrant (grey). (b) SN- or $\alpha$-Fas-induced apoptotic cell death of HeLa cells is significantly increased by the expression of Cx43. Apoptosis of HeLa-Cx43 and HeLa-CTL cells untreated or treated with increasing concentrations of SN or $\alpha$-Fas for $5 \mathrm{~h}$ was detected by annexin V-FITC/PI labelling. Mean \pm S.E.M., ${ }^{*} P<0.05$ versus untreated (NG); ${ }^{*} P<0.05$ versus CTL cells (NG); $n \geq 8$ in at least three different cell cultures. (c) Representative western blots show that apoptotic cleavage of Parp (cl. Parp) and clevage of caspase-7 (cl. Cas) (induced by $10 \mu \mathrm{M} \mathrm{SN} \mathrm{and} 100 \mathrm{ng} / \mathrm{ml} \alpha-\mathrm{Fas}$ ) is time-dependent and earlier detectable in HeLa-Cx43 cells compared with HeLa-CTL cells

untreated and SN-treated cells $(10 \mu \mathrm{M})$ showed a low basal PI uptake, which was significantly increased in the presence of the hemichannel opener ATP (Figure 5b). This ATP-induced enhancement was abolished after pretreatment with the inhibitory Pep $(50 \mu \mathrm{M})$. The ConPep did not reduce the ATP-induced PI uptake in HeLa-Cx43 cells (mean fluorescence of single cells (mean grey) untreated: 149 \pm 1 ; SN: $155 \pm 1$; ATP: $194 \pm 3$; ATP + Pep: $155 \pm 1$; ATP + ConPep: $207 \pm 2$; in three different cultures, $n \geq 80-160$; $P<0.001$ ATP/ATP + ConPep versus untreated and SN).

\section{GJ channels enhance the amount of cells responding to} $\mathrm{SN}$ with a $\mathrm{Ca}^{2+}{ }_{\mathrm{i}}$ increase. $\mathrm{Ca}^{2+}$ and inositol triphosphate $\left(\mathrm{IP}_{3}\right)$ are known to represent potential proapoptotic signal molecules, which are small enough to pass through GJs. We, therefore, analysed changes of intracellular free calcium $\left(\mathrm{Ca}^{2+}{ }_{\mathrm{i}}\right)$ in cells without GJs (CTL and Cx43CT-GFP) and in cells with functional GJs (Cx43, Cx43NT-GFP) after treatment with SN. SN $(10 \mu \mathrm{M})$ increased $\mathrm{Ca}^{2+}{ }_{i}$ in $84 \pm 5 \%$ of cells expressing full-length $\mathrm{Cx} 43$ and $59 \pm 8 \%$ of cells expressing the $\mathrm{N}$-terminal channel-building part of $\mathrm{Cx} 43$ (Cx43NT-GFP; Figure 6a). In contrast, only $27 \pm 7 \%$ of HeLa cells expressing no $\mathrm{Cx}(\mathrm{CTL})$ or $28 \pm 7 \%$ of HeLa cells expressing the channel-incompetent cytoplasmic CT of Cx43 (Cx43CT-GFP) reacted to $\mathrm{SN}$ with an increase of $\mathrm{Ca}^{2+}{ }_{\mathrm{i}}$.

Inhibition of $\mathrm{IP}_{3}$ receptor-mediated $\mathrm{Ca}^{2+}$ release diminish apoptosis in GJ-coupled HeLa-Cx43 cells. In another set of experiments (Figure 6b), preincubation (15 min) with the $\mathrm{IP}_{3}$ receptor blocker xestospongin $\mathrm{C}$ (Sigma Aldrich, Taufkirchen, Germany; $40 \mu \mathrm{M}$ ) restricted the SN-induced $\mathrm{Ca}^{2+}$ increase to $36 \pm 12 \%$ of the cells (Cx43+SN: $99 \pm 1$, $P<0.001, n=8$, in 3-4 different cultures). This number corresponds well with the amount of GJ-deficient cells responding with a $\mathrm{Ca}^{2+}{ }_{i}$ increase to stimulation with $\mathrm{SN}$ (Figure $6 \mathrm{~b}$ ). The inhibition of $\mathrm{IP}_{3}$ receptors by xestospongin $\mathrm{C}$ reduced the rate of $\mathrm{SN}$-induced apoptosis only in HeLa-Cx43 but not in HeLa-CTL cells (Figure 6c).

\section{Discussion}

In this study, we have shown that the enhancing effect of $\mathrm{Cx}$ expression on apoptosis in HeLa cells is dependent on their channel-forming capacity and their influence on channel permeability. In contrast, channel-independent effects, such as that observed to have a role in migration in the same type of cells ${ }^{5}$ or in cell proliferation as shown in Neuro2a cells, ${ }^{28}$ could not be observed. Thus, our study confirms and extends previous reports on a decisive role of gap junctional communication on augmentation of apoptosis in tumour cell lines such as BC31 (a rat bladder carcinoma cell line) ${ }^{29}$ or C6 glioma cells, ${ }^{30}$ as well as in neuronal cells, for example, astrocytes $^{31}$ and Neuro2a cells. ${ }^{32}$

Our conclusion of gap junctional communication being a prerequisite for the augmented apoptosis is based on several lines of evidence. Firstly, the pharmacologic inhibition of GJs decreased the extent of $\mathrm{SN}$ - or $\alpha$-Fas-induced apoptosis. In agreement with an inhibitory action of meclofenamic acid and heptanol on GJ coupling, ${ }^{33}$ we have shown that GJs remain open during the development of apoptosis and this concurs with results from other groups. ${ }^{30,34}$ Although the inhibitors used, meclofenamic acid and heptanol, may have unspecific effects, they did not directly interfere with apoptotic signalling processes since they did not affect the rate of apoptosis in untreated cells. Second, the decisive role of gap junctional communication but not of channel-independent effects of 
b
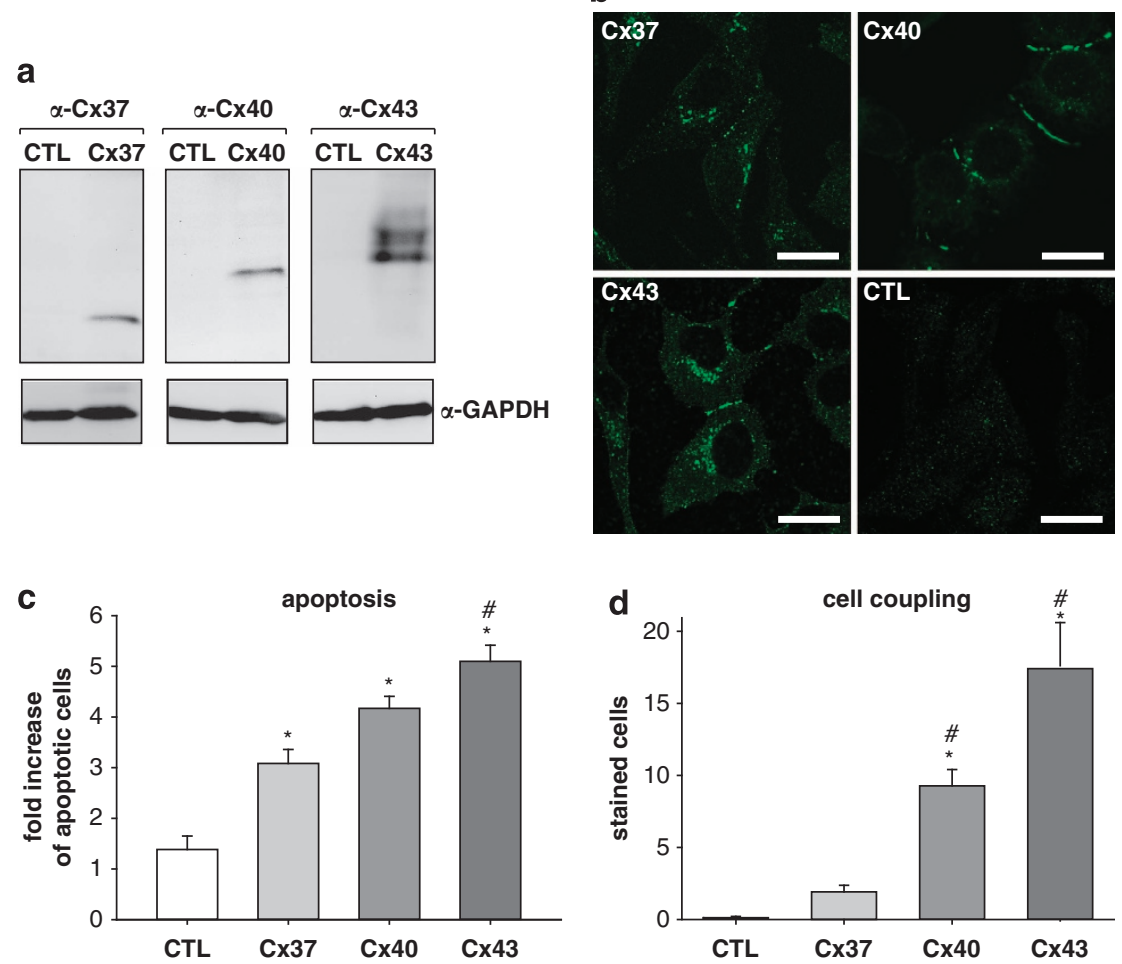

Figure 2 The rate of apoptosis is dependent on the Cx type expressed and correlates to the GJ permeability. (a) Western blot analysis for the expression of Cx37, Cx40 and Cx43 in stably transfected HeLa cells compared with empty vector-transfected HeLa (CTL). (b) Immunofluorescence stainings of Cx proteins in stably transfected HeLa cells demonstrate typical localisation at the membrane of adjacent cells. HeLa-CTL cells were used as controls and showed no Cx43 expression by staining for Cx43. (c) Apoptosis (induced by $1 \mu \mathrm{M} \mathrm{SN}, 3 \mathrm{~h}$ ) of stably transfected HeLa cells is dependent on the $\mathrm{Cx}$ type expressed and significantly increased by expression of Cx40 or Cx43 compared with HeLa-CTL. Apoptosis was determined by annexin V-FITC/PI labelling and fold increase of apoptotic cells is expressed as mean \pm S.E.M.; ${ }^{*} P<0.05$ versus CTL; ${ }^{~} P<0.05$ versus $C \times 37 ; n \geq 5$ in at least three different cell cultures. (d) Gap junctional cell coupling of HeLa cells varies with the $C x$ type expressed and correlates with the rate of apoptosis. Cell coupling was measured by dye spreading (Alexa Fluor 488). The number of dye-stained cells is displayed as mean \pm S.E.M. ( $n \geq 18$ dye injections in $\geq 3$ different cell cultures; ${ }^{*} P<0.05$ versus $\mathrm{CTL}$; ${ }^{\#} P<0.05$ versus $\mathrm{Cx37}$; NG). GAPDH, glyceraldehyde 3-phosphate dehydrogenase

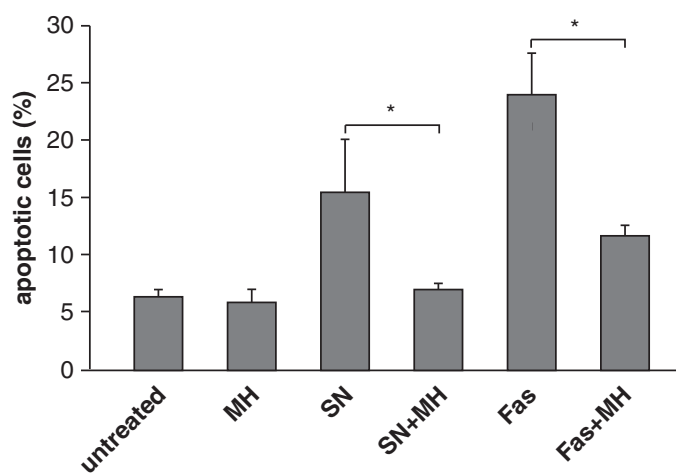

Figure 3 Impact of gap junctional communication on apoptosis of HeLa cells. Apoptosis induced by SN $(1 \mu \mathrm{M}, 5 \mathrm{~h})$ or $\alpha$-Fas $(100 \mathrm{ng} / \mathrm{ml}, 5 \mathrm{~h})$ in HeLa-Cx43 cells is significantly reduced by blocking the GJ channels with meclofenamic acid $(\mathrm{M}, 100 \mu \mathrm{M})$ and heptanol $(\mathrm{H}, 0.25 \mathrm{mM})$. Apoptosis was measured by annexin V-FITC/PI staining and quantified using flow cytometry. The percentage of apoptotic cells from the total cell number is expressed as mean \pm S.E.M. ${ }^{*} P<0.05 ; \mathrm{NG} ; n \geq 3$ in at least three different cell cultures

Cx43 could be confirmed by our results obtained in HeLa cells expressing truncated variants of $\mathrm{Cx} 43$. We have shown before that cells expressing the N-terminal part (NT) of Cx43 are able to form functional GJs, whereas cells expressing the C terminus of $\mathrm{Cx} 43$ did not. ${ }^{5}$ Accordingly, SN-induced apoptosis was only augmented in cells expressing the $\mathrm{N}$-terminal channel-building part but not in cells expressing the C-terminal cytoplasmic part of $\mathrm{Cx} 43$. We conclude that the expression of functional Cx43 GJ channels is required for enhancement of apoptosis.

A further piece of evidence that gap junctional communication enhances apoptosis can be deducted from the observation that the rate of apoptosis was clearly dependent on the permeability of the gap junctions as determined by the $\mathrm{Cx} \mathrm{s}$ studied here: $\mathrm{Cx} 43 \geq \mathrm{C} \times 40 \geq \mathrm{Cx} 37>\mathrm{Cx}$-deficient controls. These $\mathrm{Cx}$-dependent differences in GJ permeabilities are in agreement with own previous observations ${ }^{35}$ and another recently published study, showing the highest dye transfer for Cx43-composed channels, followed by Cx40 channels and lowest transfer for $\mathrm{C} \times 37$ channels. ${ }^{36}$ Of note, our results are based on the use of the GJ-permeant dye Alexa Fluor 488. Although the cellular exchange of GJ-permeant dyes between cells can differ with respect to their size and surface charge and may not represent the permeability of any potential proapoptotic molecule, ${ }^{36,37}$ it underpins a close connection between gap junctional permeability and augmentation of apoptosis in the experiments reported here. However, the finding that the spreading of $\mathrm{Ca}^{2+}$ signals through GJs showed a similar behaviour than Alexa Fluor 488 suggests that the different permeabilities are not unique for this dye. 
Our study shows a role of gap junctional communication on apoptosis for both the exogenous and endogenous pathway as induced by two different stimuli. Although our study does not allow to conclude that there is a general role of gap junctional communication in the control of apoptosis, it is not limited to a single stimulus. Furthermore, a more general role of gap junctional communication is suggested by the observation that cells in a cluster are more susceptible to the induction of apoptosis than single cells. ${ }^{29,31}$ However, our experiments also clearly show that gap junctional communication is not an essential prerequisite for the development of apoptosis but rather enhances its development.

Several studies have implicated a role of hemichannels in cell survival and death. ${ }^{8,10,38,39}$ Although Cx s can form hemichannels that could enable the release of pro-apoptotic signals independent of gap junctions, we found no evidence

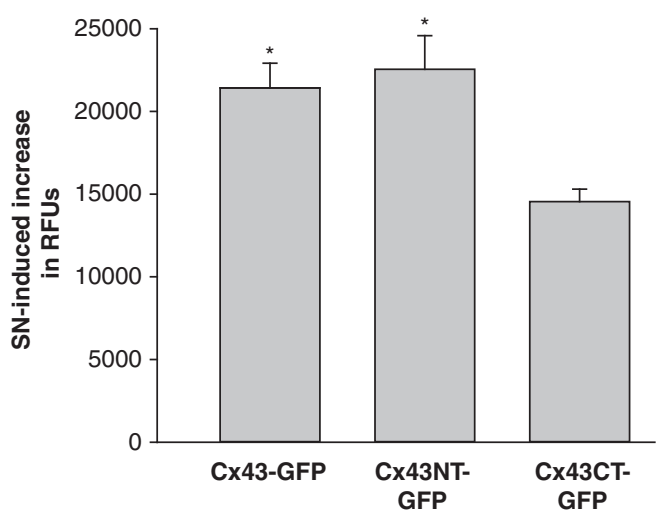

Figure 4 The channel-building part of $\mathrm{C} 43$ mediates enhanced apoptosis. SN-induced apoptosis $(1 \mu \mathrm{M}, 16 \mathrm{~h})$ of HeLa cells expressing green fluorescent protein (GFP)-labelled $\mathrm{Cx} 43$ or truncated $\mathrm{C} \times 43$ proteins was determined by caspase activation. SN-induced apoptosis of HeLa cells expressing full-length Cx43 (Cx43GFP) or the channel-building part of $\mathrm{Cx43}$ (Cx43NT-GFP) was significantly enhanced compared with cells expressing the cytoplasmic part of Cx43 (Cx43CTGFP). RFUs indicating activation of caspases in apoptotic cells are depicted as mean \pm S.E.M.; ${ }^{*} P<0.05$ versus $\mathrm{C} \times 43 \mathrm{CT}$-GFP, NG; $n \geq 3$ in different cell cultures for such a mechanism in our experimental setting. A hemichannel-blockingPep, ${ }^{27}$ which did not affect gap junctional coupling could not decrease SN- or $\alpha$-Fas-induced apoptosis in Cx43-expressing HeLa cells. The fact that the cellular uptake of PI in the presence of ATP as reported elsewhere ${ }^{40}$ could be blocked by preincubation with the hemichannel-blocking Pep confirmed its expected inhibitory action in our experimental setting.

Obviously, the requirement of functional GJs for the augmentation of apoptosis suggests that some proapoptotic signals may be exchanged between apoptotic cells and their neighbours. Such signals cannot comprise caspases or proapoptotic regulator proteins like bad or bax, as these molecules are too large to pass GJs, which allow passage only for molecules up to $1.8 \mathrm{kDa} .{ }^{41}$ Small-molecule candidates that have been suggested to be potential death mediators when transferred via GJs are $\mathrm{Ca}^{2+}, \mathrm{IP}_{3}$ and cAMP. ${ }^{1,42}$ Several apoptosis-inducing stimuli are known to affect $\mathrm{Ca}^{2+}{ }_{\mathrm{i} .} \mathrm{Ca}^{2+}$ signals in turn can lead to the activation of caspases, the mainstream apoptosis executioners and opening of mitochondrial permeability transition pores (PTPs). PTP formation and opening result in the release of cytochrome $C$, which in turn has a role in the activation of the caspase cascade, and other proapoptotic proteins. ${ }^{1,43}$ The impact of the GJ-permeable molecule $\mathrm{IP}_{3}$ on apoptosis is related to $\mathrm{IP}_{3}$-triggered $\mathrm{Ca}^{2+}$ release, whereby it contributes to the induction of apoptotic cell events. ${ }^{1,42}$ The importance of $\mathrm{Ca}^{2+}$ as a proapoptotic signal has been shown by the treatment of cells with the calcium ionophore ionomycin or with thapsigargin. Such induced sustained elevation of $\mathrm{Ca}^{2+}$ was sufficient to trigger apoptosis without any other apoptosis-inducing stimuli. ${ }^{44,45}$

We analysed whether changes of $\mathrm{Ca}^{2+}{ }_{i}$ could be involved into the enhanced rate of apoptosis observed in cells coupled by gap junctions. Indeed, treatment with $\mathrm{SN}$ resulted in a fast increase of $\mathrm{Ca}^{2+}{ }_{i}$. An increase of $\mathrm{Ca}^{2+}{ }_{i}$ upon treatment with $\mathrm{SN}$ has been described previously in lymphoblastoid cells. ${ }^{46}$ However, in cells without gap junctional coupling, only a minor
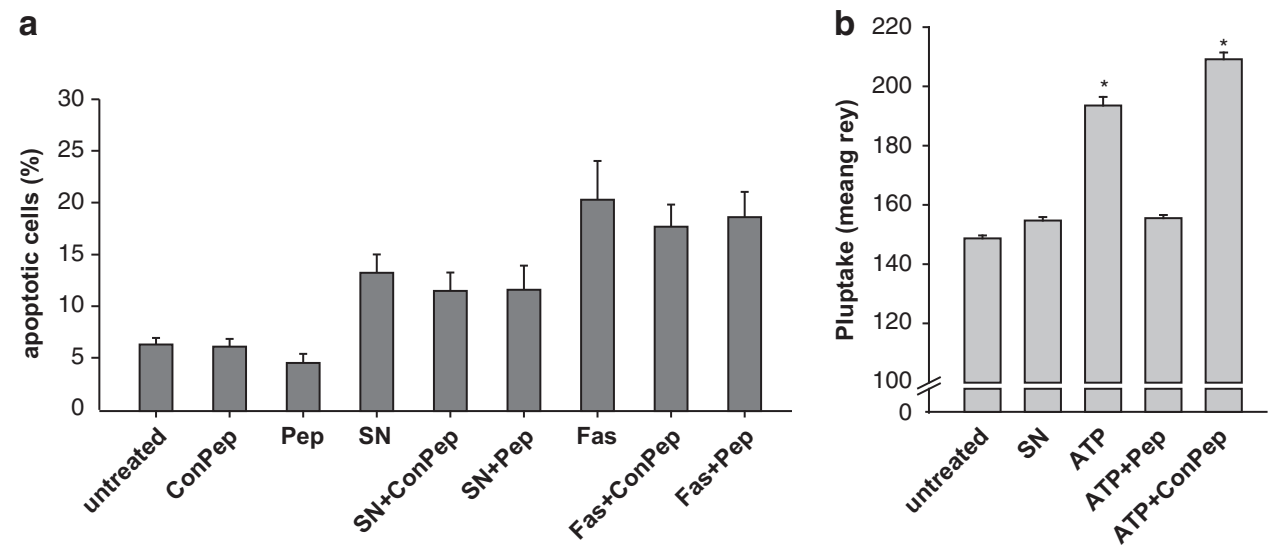

Figure 5 Effect of hemichannels on apoptosis. (a) The inhibition of $\mathrm{Cx} 43$ hemichannels with a blocking Pep ( $50 \mu \mathrm{M}$, Pep) does not affect the rate of apoptosis induced by SN $(10 \mu \mathrm{M}, 5 \mathrm{~h})$ or $\alpha$-Fas $(100 \mathrm{ng} / \mathrm{ml}, 5 \mathrm{~h})$ in HeLa-Cx43 cells. A non-inhibitory ConPep $(50 \mu \mathrm{M})$ was used as a control. Apoptosis was measured by annexin V-FITC/PI staining and quantified using flow cytometry. The percentage of apoptotic cells from the total cell number is expressed as mean \pm S.E.M.; $n \geq 6$ in at least three different cell cultures. (b) The uptake of PI (mean red fluorescence of single cells) by HeLa-Cx43 cells from the culture medium could be stimulated by opening the hemichannels with ATP (50 $\mu \mathrm{M}$ ) and was efficiently blocked by preincubation with a hemichannel-blocking Pep $(50 \mu \mathrm{M})$. Treatment with SN (10 $\mu \mathrm{M})$ did not affect the Pl uptake. A non-inhibitory Pep (ConPep) was used as a control. PI uptake of single cells is displayed as mean \pm S.E.M.; $n \geq 80-160$ cells in at least three different cell cultures ${ }^{*} P<0.001$ versus untreated, SN and ATP + ConPep, NG 

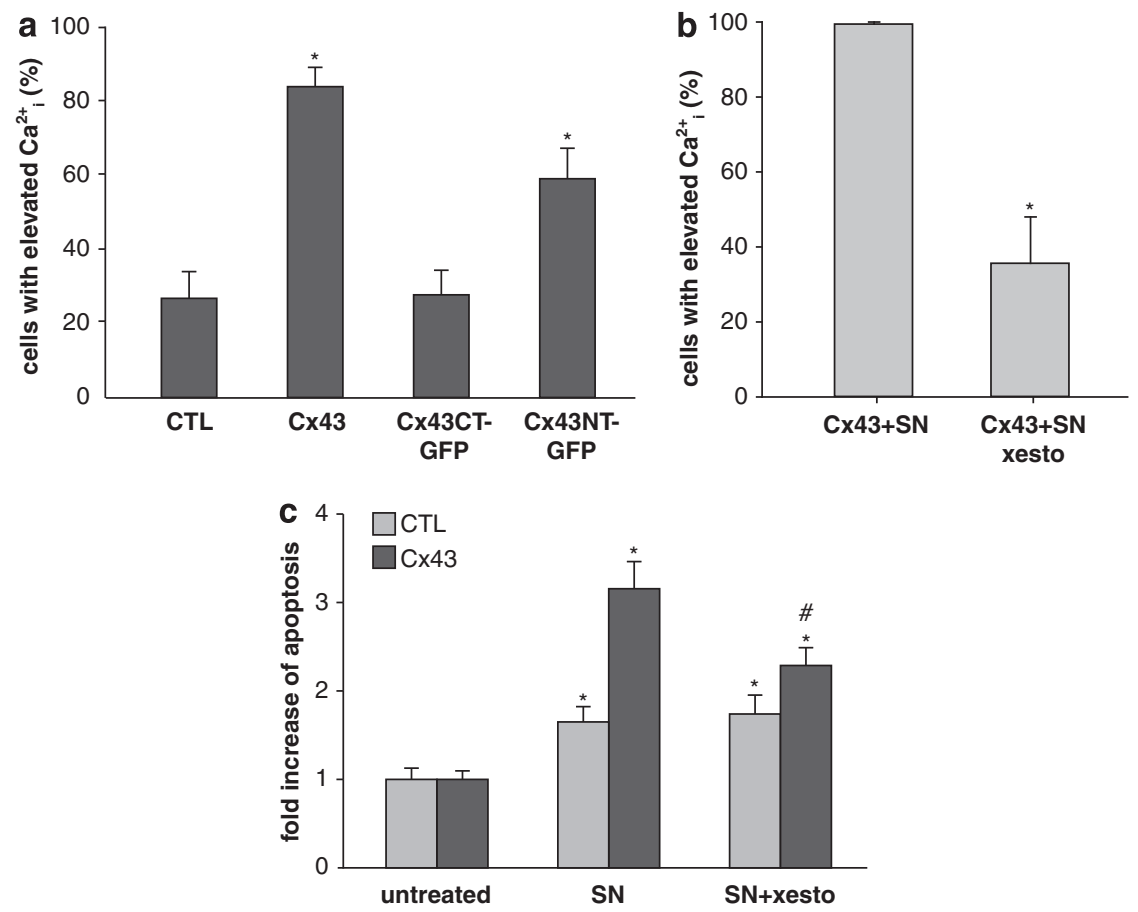

Figure 6 The immediate $\mathrm{Ca}^{2+}{ }_{j}$ response is increased in cells expressing functional $\mathrm{Cx} 43$ channels. (a) The number of cells responding within 3 min with a Ca ${ }^{2+}{ }_{i}$ increase due to SN treatment $(10 \mu \mathrm{M})$ was significantly enhanced in Cx43- and Cx43NT-expressing HeLa cells compared with HeLa-CTL or HeLa-Cx43CT cells. The percentage of cells with $\mathrm{a} \mathrm{Ca}^{2+}{ }_{\text {i }}$ increase from the total cell number is expressed as mean \pm S.E.M.; ${ }^{*} P<0.05$ versus CTL/Cx43CT, $n \geq 8$ in at least three different cell cultures. In another series of experiments (b), the $\mathrm{Ca}^{2+}$ increase induced by SN $(10 \mu \mathrm{M})$ was blocked by preincubation ( $15 \mathrm{~min}$ ) with xestospongin $\mathrm{C}$ (xesto, $\left.40 \mu \mathrm{M}\right)$. The percentage of cells with $\mathrm{a} \mathrm{Ca}^{2+}{ }_{\text {i }}$ increase from the total cell number is expressed as mean \pm S.E.M.; ${ }^{*} P<0.05, N G ; n=8$ in three different cell cultures. (c) Inhibition of $I_{3}$-mediated Ca ${ }^{2+}$ release (by xesto, $40 \mu \mathrm{M})$ reduces significantly SN $(10 \mu \mathrm{M}, 5 \mathrm{~h})$-induced apoptosis of HeLa-Cx43 cells but does not affect Cx-deficient control cells. Apoptosis was determined by annexin V-FITC/PI labelling and fold increase of apoptotic cells is expressed as mean \pm S.E.M.; ${ }^{*} P<0.05$ versus corresponding untreated; ${ }^{*} P<0.05$ versus $\mathrm{Cx} 43 \mathrm{SN} ; n=6$ in three different cell cultures

part responded with a $\mathrm{Ca}^{2+}{ }_{\mathrm{i}}$ increase, whereas virtually all cells responded when the cells were coupled. Interestingly, pretreatment with the $\mathrm{IP}_{3}$ receptor inhibitor xestospongin $\mathrm{C}^{47}$ limited the calcium response to a fraction of cells, which was numerically identical with the fraction of cells that responded in the absence of gap junctions. We have shown before that xestospongin $\mathrm{C}$ reliably abolished $\mathrm{IP}_{3}$-mediated $\mathrm{Ca}^{2+}$ responses. ${ }^{33}$ Therefore, our findings are consistent with the view that $\mathrm{SN}$ induced an $\mathrm{IP}_{3}$-independent increase of $\mathrm{Ca}^{2+}{ }_{i}$ in $\mathrm{SN}$-sensitive cells. This $\mathrm{Ca}^{2+}$ signal could have spread to neighbouring cells via GJs, which is also consistent with our findings that part of the cells responded with a delayed $\mathrm{Ca}^{2+}{ }_{i}$ increase (up to $30 \mathrm{~s}$ ) upon SN treatment (data not shown). As shown before, an increase of $\mathrm{Ca}^{2+}{ }_{i}$ can induce a secondary release of calcium via $\mathrm{IP}_{3}$ receptors, ${ }^{48}$ which in our setting may have spread via GJs to non-SN-responsive neighbouring cells to induce increases of $\mathrm{Ca}^{2+}{ }_{i}$ as well. Thus, both absence of gap junctional communication and inhibition of $\mathrm{IP}_{3}$ receptors may restrict apoptosis by the same amount as observed here. We have recently described that a similar mechanism plays a pivotal role in the $\mathrm{Ca}^{2+}$ response of endothelial cells to stimulation with histamine or ATP. ${ }^{49} \mathrm{Ca}^{2+}{ }_{i}$ increases were also reported for Fas-initiated apoptosis with a sustained increase in $\mathrm{Ca}^{2+}{ }_{\mathrm{i}}$ commencing between 1 and $2 \mathrm{~h}$ after treatment. ${ }^{50,51}$

In agreement with our study, it has been reported that the blockade of intercellular communication via GJs attenuated the extent of apoptosis, for example, in BC31 cells, ${ }^{29}$ granulosa cells ${ }^{52}$ or astrocytes. ${ }^{53}$ A so-called bystander death induced by gap junctional spreading of cell-killing signals from cells undergoing apoptosis to healthy surrounding cells has been described for several apoptosis-inducing conditions. $^{21,22}$ Although the physiologic role of a spread of apoptosis signals to potentially healthy neighbouring cells remains a matter of debate, the passage of 'death signals', for example, from lethally irradiated cells to their neighbours via GJs ${ }^{54,55}$ seems to be very promising for cancer therapies. ${ }^{56}$ GJ-mediated bystander effects are described also for a few diseases, for example, retinitis pigmentosa ${ }^{57}$ or HIV-1 infection, ${ }^{58}$ and may represent a potentially important therapeutic principle in these disease states.

In conclusion, our study has shown that Cx expression enhances apoptosis induction. This is not a class effect but varies considerably dependent on the type of the $\mathrm{Cx}$ as studied here for $\mathrm{Cx}$ being expressed in vascular tissue. Our results suggest that this effect is due to the transfer of proapoptotic signals, among which $\mathrm{IP}_{3}$ may play a significant role. Thus, gap junctional communication and the control of gap junctional permeability by variation of $\mathrm{Cx}$ expression may be a potential target for therapeutic control of apoptosis.

\section{Materials and Methods}

Cell cultures. HeLa cells stably transfected with murine $\mathrm{C} \times 37$, murine $\mathrm{C} \times 40$ or rat Cx43 were kindly provided by Dr. Klaus Willecke (University of Bonn, Bonn, Germany). HeLa cells transfected with the empty vector pBEHpac18 (CTL; kindly provided by Dr. Willecke, Bonn, Germany) using SuperFect (Qiagen, Hilden, 
Germany), which served as controls. Generation of stably transfected HeLa cells expressing the NT (amino acids (aa) 1-257, Cx43NT-GFP) or the CT of Cx43 (aa 257-382, Cx43CT-GFP) was described previously. ${ }^{5}$ Cells were cultured in Dulbecco's modified Eagle's medium (DMEM; Invitrogen, Life Technologies, Darmstadt, Germany) with 10\% new born calf serum (Biochrom, Berlin, Germany), penicillin (100 U/ml; Sigma Aldrich) and streptomycin $(100 \mu \mathrm{g} / \mathrm{ml}$; Sigma Aldrich) at $37^{\circ} \mathrm{C}$ and $5 \% \mathrm{CO}_{2}$. Growth medium of stably transfected HeLaCTL, HeLa-Cx37, HeLa-Cx40 and HeLa-Cx43 was supplemented with puromycin $(1 \mu \mathrm{g} / \mathrm{ml}$; Sigma Aldrich) and of HeLa-Cx43NT-GFP and HeLa-Cx43CT-GFP with zeocin $(200 \mu \mathrm{g} / \mathrm{ml}$; Invitrogen, Life Technologies). Apoptosis was induced with SN (Sigma Aldrich) or $\alpha$-Fas antibody (Millipore Merck, Schwalbach, Germany) as indicated.

Annexin V-FITC/PI staining. The annexin V-FITC apoptosis detection kit (BD Biosciences, Heidelberg, Germany) was used according to the manufacturer's recommendations. The cells were treated as indicated, detached with Accutase (PAA Laboratories, Coelbe, Germany) and collected by centrifugation (1500 r.p.m. $5 \mathrm{~min})$. Cell pellets were washed with phosphate-buffered saline (PBS) resuspended in $1 \times$ binding buffer $(0.01 \mathrm{M}$ HEPES/ $\mathrm{NaOH}, \mathrm{pH} 7.4,140 \mathrm{mM} \mathrm{NaCl}$ and $2.5 \mathrm{mM} \mathrm{CaCl}$ ), and stained with annexin V-FITC and PI for $15 \mathrm{~min}$ at room temperature in the dark. A total of 10000 cells of each sample were analysed by fluorescence-activated cell sorting (FACSort; BD Bioscience). Apoptotic cells were defined as annexin V-FITC-positive and PI-negative cells.

Western blot analysis. Empty vector-transfected HeLa cells (CTL) or HeLa cells stably expressing $\mathrm{C} \times 37, \mathrm{Cx} 40$ or $\mathrm{C} \times 43$ were seeded in 6-well plates and lysed in Laemmli buffer ${ }^{59}$ the next day. The samples were boiled for $5 \mathrm{~min}$ and size-separated by SDS-PAGE using 8-16\% Tris-glycine gels (Thermo Scientific, Bonn, Germany). The proteins were electrophoretically transferred to a Hybond-P membrane (Amersham, GE Healthcare, Freiburg, Germany) at $0.8 \mathrm{~mA} / \mathrm{cm}^{2}$ for $1 \mathrm{~h}$ and unspecific antibody binding was blocked by $5 \%$ skimmed milk powder (AppliChem, Darmstadt, Germany) in PBS solution containing 0.1\% Tween-20 (Sigma Aldrich) for $1 \mathrm{~h}$ at room temperature. The membranes were incubated with rabbit $\alpha$-Cx37 (1:1000; Alpha Diagnostic, Biotrend, Koeln, Germany), rabbit $\alpha-C \times 40$ (1:1000; Alpha Diagnostic) or rabbit $\alpha-C \times 43$ (1:1000; Sigma Aldrich) overnight at $4{ }^{\circ} \mathrm{C}$. After washing with PBS- $0.1 \%$ Tween, the blots were incubated for $2 \mathrm{~h}$ with the secondary antibody coupled to horseradish peroxidase $(1: 1000$; Calbiochem, Merck, Darmstadt, Germany). Primary antibodies were diluted in $5 \%$ bovine serum albumin (BSA; AppliChem) in PBS-0.1\% Tween and secondary antibodies in $5 \%$ skimmed milk powder in PBS- $0.1 \%$ Tween. The blots were washed four times for $10 \mathrm{~min}$ each and bound antibodies were detected using a chemiluminescence detection kit for horseradish peroxidase (AppliChem).

To analyse the apoptotic cleavage of caspase-7 and Parp in HeLa-Cx43 and HeLa-CTL cells, the cells were seeded in 6-well-plates to $80 \%$ confluence. On the next day, the cells were treated with $10 \mu \mathrm{M} \mathrm{SN}$ (Sigma Aldrich) or $100 \mathrm{ng} / \mathrm{ml} \alpha$-Fas (Millipore) for the indicated time points and lysed in Laemmli buffer. ${ }^{59}$ For detection of cleaved Parp, an $\alpha$-Parp antibody (1:500; Cell Signaling, NEB, Frankfurt am Main, Germany), and for cleaved caspase-7, an $\alpha$-caspase-7 antibody (1:500; Cell Signaling), was used. Detection of GAPDH ( $\alpha$-GAPDH, $1: 10000$; Chemicon, Merck Chemicals, Schwalbach, Germany) was used to demonstrate equal loading.

Immunofluorescence staining. HeLa cells expressing $\mathrm{C} \times 37, \mathrm{C} \times 40$ or Cx43 or HeLa-CTL cells were seeded on glass coverslips. On the next day, the cells were fixed with $3.7 \%$ formaldehyde in PBS for $20 \mathrm{~min}$ at room temperature. After rinsing with PBS, cells were permeabilised with $0.1 \%$ Triton X-100 (AppliChem) in PBS for 4 min. Unspecific antibody binding was blocked with PBS containing $0.5 \%$ BSA for $1 \mathrm{~h}$. Cells were incubated with rabbit $\alpha-\mathrm{C} \times 37$ (Alpha Diagnostic; $1: 100$ ), rabbit $\alpha-\mathrm{C} \times 40$ (Alpha Diagnostic; $1: 100$ ) or rabbit $\alpha$-Cx43 (Sigma Aldrich; $1: 100$ ) overnight at $4{ }^{\circ} \mathrm{C}$. The cells were washed and incubated with a secondary antibody $(1: 200)$ coupled to the fluorochrome Alexa Fluor 488 (Invitrogen) for $1 \mathrm{~h}$ at room temperature. Coverslips were mounted and expression and localisation of the $\mathrm{Cx}$ proteins were analysed using confocal microscopy (Leica, Wetzlar, Germany).

Detection of apoptosis in cells with inhibited gap junctional coupling. To investigate the impact of GJs on the rate of apoptosis, HeLaCx43 cells were incubated with meclofenamic acid (M; $100 \mu \mathrm{M}$; Sigma Aldrich) and heptanol $(\mathrm{H} ; 0.25 \mathrm{mM}$; Sigma Aldrich), which nearly abolished the gap junctional coupling and minimised the drugs' side effects. ${ }^{33}$ To induce apoptosis, the cells were additionally treated with $1 \mu \mathrm{M} \mathrm{SN}$ or $100 \mathrm{ng} / \mathrm{ml} \alpha$-Fas for $5 \mathrm{~h}$ and the amount of apoptotic cells was quantified by flow cytometry with annexin V-FITC staining as described above.

FLICA staining. Apoptosis was measured with the sulforhodamine FLICA apoptosis detection kit (Immunochemistry Technologies, Biomol, Hamburg, Germany). The red fluorescent inhibitor of caspases SR-VAD-FMK detects activated caspases (caspase-1, -3, -4, -5, -6, -7, -8 and -9) of apoptotic cells. Untreated or SN-treated $(1 \mu \mathrm{M}, 16 \mathrm{~h})$ HeLa cells expressing full-length CX43-GFP, Cx43NT-GFP or Cx43CT-GFP were detached with trypsin-EDTA (Sigma Aldrich) and $300 \mu \mathrm{l}$ cell suspension $\left(5 \times 10^{6}\right.$ cells per ml) were stained with FLICA reagent according to the manufacturer's instructions. After staining, the cells were washed three times with $1 \times$ wash buffer and cell concentrations of untreated and $\mathrm{SN}$-treated cells were determined again. After equilibration of the cell concentrations, the cells were resuspended in PBS and the red fluorescence intensity of sulforhodamine (RFU) was measured in a fluorescence plate reader at excitation/emission wavelengths of 550/595 nm.

Analysis of GJ-independent transfer of proapoptotic signals via hemichannels. The effect of hemichannels on the rate of apoptosis was analysed with a hemichannel-blocking Pep. HeLa-Cx43 cells were incubated with a Cx43-specific Pep (H-Val-Asp-Cys-Phe-Leu-Ser-Arg-Pro-Thr-Glu-Lys-Thr-OH; $50 \mu \mathrm{M}$; Biosyntan, Berlin, Germany), which reportedly inhibits hemichannels at a concentration of $50 \mu \mathrm{M}$ by affecting the extracellular loop of Cx43. ${ }^{27}$ For control experiments, cells were incubated with $50 \mu \mathrm{M}$ ConPep (H-Gly-Asp-Glu-Gln-SerAla-Phe-Arg-Cys-Asn-Thr-Gln-OH). Apoptosis was induced by the addition of SN $(10 \mu \mathrm{M})$ or $\alpha$-Fas $(100 \mathrm{ng} / \mathrm{ml})$ for $5 \mathrm{~h}$ and the amount of apoptotic cells was measured by annexin V-FITC/PI staining.

PI uptake via hemichannels. To analyse the activity of hemichannels, HeLa-Cx43 cells were incubated with PI $(20 \mu \mathrm{g} / \mathrm{ml}, 10 \mathrm{~min})$ and fluorescence images (excitation: $546 \mathrm{~nm}$; emission: $570 \mathrm{~nm}$; exposure time $1000 \mathrm{~ms}$; experimental set-up: see calcium measurements) were taken immediately after washout of PI. The mean fluorescence (mean grey value) of single cells was calculated by the the Till Vision software (Till Photonics, Gräfelfing, Germany). To verify that the $\mathrm{PI}$ uptake is not due to cell death, the cells were stained with Trypan blue afterwards and blue stained cells were excluded from calculations. Hemichannels were activated by ATP $(50 \mu \mathrm{M})$.

Measurement of the $\mathrm{Ca}^{2+}{ }_{\mathrm{i}}$. Intracellular changes of free $\mathrm{Ca}^{2+}$ were detected with the $\mathrm{Ca}^{2+}$-sensitive dye Fura2 (Invitrogen). After incubation with $4 \mu \mathrm{M}$ Fura2 solved in DMEM $\left(30 \mathrm{~min}\right.$ at $37^{\circ} \mathrm{C}$ and $\left.5 \% \mathrm{CO}_{2}\right)$, HeLa cells (grown on coverslips) were washed two times, transferred to the experimental chamber (which had a wide opening on the top) and incubated in HEPES (pH 7.4; $125 \mathrm{mM}$ $\mathrm{NaCl}, 3 \mathrm{mM} \mathrm{KCl}, 1.25 \mathrm{mM} \mathrm{NaH}_{2} \mathrm{PO}_{4}, 2.5 \mathrm{mM} \mathrm{CaCl}_{2}, 1.5 \mathrm{mM} \mathrm{MgCl}, 10 \mathrm{mM}$ glucose). The chamber filled with $200 \mu$ l HEPES was mounted on an inverted microscope (Axiovert S100; Zeiss, Göttingen, Germany).

The $\mathrm{Ca}^{2+}$-sensitive dye was alternatively excited at 340 and $380 \mathrm{~nm}$ and the signal was detected at $505 \mathrm{~nm}$ with a computerised system (Till Photonics). Frames at 340 and $380 \mathrm{~nm}$ of the analysed areas $(640 \mathrm{~nm} \times 480 \mathrm{~nm})$ were stored every $500 \mathrm{~ms}$ for $3 \mathrm{~min}$ and the signal ratio corrected for the background was determined for each pixel after the experiment. Based on changes of the mean ratio of single cells over time, the percentage of cells showing a $\mathrm{Ca}^{2+}{ }_{i}$ increase due to stimulation (reacting cells per cells in the visible area) was calculated. No attempt was made to calculate the exact $\mathrm{Ca}^{2+}{ }_{i}$ concentration from the ratio.

Cells were stimulated mechanically or by the addition of SN $(10 \mu \mathrm{M})$. Mechanical stimulation of single cells by touching with glass pipettes (tip diameter $1 \mu \mathrm{m}$ ) increased the $\mathrm{Ca}^{2+}$, of the stimulated cell. In the presence of apyrase (Sigma Aldrich; $50 \mathrm{U} / \mathrm{ml}$ ), which degraded the ATP released due to the stimulation, the $\mathrm{Ca}^{2+}$ signal spread to neighbouring cells via gap junctions. The number of cells showing an elevated $\mathrm{Ca}^{2+}$ level (except of the stimulated cell) was counted. In another set of experiments, SN was solved in double concentration $(20 \mu \mathrm{M})$ in HEPES and $200 \mu$ lof this solution was rapidly added to the cells ( $120 \pm 14$ cells per visual field were counted). Addition of the solution without stimuli did not change the $\mathrm{Ca}^{2+}$ is signals. $\mathrm{SN}$ did not change the $\mathrm{pH}$ of the HEPES solution. $\mathrm{IP}_{3}$ receptors were inhibited by preincubation ( $15 \mathrm{~min})$ with xestospongin $\mathrm{C}(40 \mu \mathrm{M})$.

Dye coupling. Gap junctional coupling was detected by injecting a GJ-permeable, membrane-impermeable fluorescent dye $(3.5 \mathrm{mM}$ Alexa Fluor 488 dissolved in $150 \mathrm{mM} \mathrm{KCl}$; Invitrogen) into single cells and analysing the dye 
spreading within $5 \mathrm{~min}$. The cell incubation unit and experimental settings were the same as for the $\mathrm{Ca}^{2+}{ }_{i}$ measurement. The dye was injected using a dye-filled borosilicate micropipette (at a tip pressure of $60 \mathrm{~mm} \mathrm{Hg}$ for $0.6 \mathrm{~s}$, tip diameter $<1 \mu \mathrm{m}$ ) connected to an injecting system (FemtoJet; Eppendorf, WesselingBerzdorf, Germany). The fluorescent dye was excited at $488 \mathrm{~nm}$ and fluorescence signals were detected using a long-pass emission filter $\lambda_{\mathrm{em}} \geq 515 \mathrm{~nm}$. Following dye injection, images were captured using a digital camera (Imago; Till Photonics) that was mounted on the inverted microscope (Axiovert S100; Zeiss). To assess cellular coupling, the total number of dye-stained cells at the 5-min postinjection timepoint was counted.

Statistics. Gaussian distributed data were analysed for statistically significant differences by the Student's t-test (two groups, unpaired data). Differences between more than two groups were determined by one-way ANOVA, followed by Student-Newman-Keuls method for multiple comparisons. Error probabilities of $P \leq 0.05$ were considered significant. All values are expressed as means \pm S.E.M. Non-Gaussian distributed data (indicated as ' $N G$ ' in the figure legends) were analysed by the non-parametric Mann-Whitney rank-sum test. For multiple comparisons, the Kruskal-Wallis test on ranks followed by pairwise multiple comparisons with Dunn's method was used. Although these tests do not allow analysing differences of mean values, for descriptive reasons mean values are presented throughout the manuscript. Medians are not displayed as they did not differ from the means more than $20 \%$.

\section{Conflict of Interest}

The authors declare no conflict of interest.

Acknowledgements. We thank Silvia Münzing, Dorothea Gössel and Katarzyna Stefanowski for excellent technical assistance and Dr. Klaus Willecke (Institute of Genetics, University of Bonn) for kindly providing HeLa cells, HeLa cells stably transfected with mouse $\mathrm{C} \times 37$, mouse $\mathrm{C} \times 40$ and rat $\mathrm{C} \times 43$ and the plasmid pBEHpac18. This work was supported by grants from the Deutsche Forschungsgemeinschaft (DFG-PO 414/2-1 to UP and KP).

1. Krysko DV, Leybaert L, Vandenabeele P, D'Herde K. Gap junctions and the propagation of cell survival and cell death signals. Apoptosis 2005; 10: 459-469.

2. Rodriguez-Sinovas A, Cabestrero A, Lopez D, Torre I, Morente M, Abellan A et al. The modulatory effects of connexin 43 on cell death/survival beyond cell coupling. Prog Biophys Mol Biol 2007; 94: 219-232.

3. Wei CJ, Xu X, Lo CW. Connexins and cell signaling in development and disease. Annu Rev Cell Dev Biol 2004; 20: 811-838.

4. Jiang JX, Gu S. Gap junction- and hemichannel-independent actions of connexins. Biochim Biophys Acta 2005; 1711: 208-214.

5. Behrens J, Kameritsch P, Wallner S, Pohl U, Pogoda K. The carboxyl tail of Cx43 augments p38 mediated cell migration in a gap junction-independent manner. Eur $\mathrm{J}$ Cell Biol 2010; 89: 828-838.

6. Bates DC, Sin WC, Aftab Q, Naus CC. Connexin43 enhances glioma invasion by a mechanism involving the carboxy terminus. Glia 2007; 55: 1554-1564.

7. Kameritsch P, Pogoda K, Pohl U. Channel-independent influence of connexin 43 on cell migration. Biochim Biophys Acta 2012; 1818: 1993-2001.

8. Decrock E, De Vuyst E, Vinken M, Van Moorhem M, Vranckx K, Wang N et al. Connexin 43 hemichannels contribute to the propagation of apoptotic cell death in a rat $\mathrm{C} 6$ glioma cell model. Cell Death Differ 2009; 16: 151-163.

9. Decrock E, Vinken M, De Vuyst E, Krysko DV, D'Herde K, Vanhaecke T et al. Connexinrelated signaling in cell death: to live or let die? Cell Death Differ 2009; 16: 524-536.

10. Hur KC, Shim JE, Johnson RG. A potential role for cx43-hemichannels in staurosporininduced apoptosis. Cell Commun Adhes 2003; 10: 271-277.

11. Kalvelyte A, Imbrasaite A, Bukauskiene A, Verselis VK, Bukauskas FF. Connexins and apoptotic transformation. Biochem Pharmacol 2003; 66: 1661-1672.

12. Plotkin LI, Bellido T. Bisphosphonate-induced, hemichannel-mediated, anti-apoptosis through the Src/ERK pathway: a gap junction-independent action of connexin 43. Cell Commun Adhes 2001; 8: 377-382.

13. lacobas DA, Urban-Maldonado M, lacobas S, Scemes E, Spray DC. Array analysis of gene expression in connexin-43 null astrocytes. Physiol Genom 2003; 15: 177-190.

14. Huang RP, Hossain MZ, Huang R, Gano J, Fan Y, Boynton AL. Connexin 43 (cx43) enhances chemotherapy-induced apoptosis in human glioblastoma cells. Int $\mathrm{J}$ Cancer 2001; 92: 130-138.

15. Sato H, Iwata H, Takano Y, Yamada R, Okuzawa H, Nagashima $Y$ et al. Enhanced effect of connexin 43 on cisplatin-induced cytotoxicity in mesothelioma cells. J Pharmacol Sci 2009; 110: $466-475$.
16. Boengler K, Dodoni G, Rodriguez-Sinovas A, Cabestrero A, Ruiz-Meana M, Gres P et al. Connexin 43 in cardiomyocyte mitochondria and its increase by ischemic preconditioning. Cardiovasc Res 2005; 67: 234-244.

17. Halestrap AP. Mitochondria and preconditioning: a connexin connection? Circ Res 2006; 99: 10-12.

18. Li H, Brodsky S, Kumari S, Valiunas V, Brink P, Kaide J et al. Paradoxical overexpression and translocation of connexin43 in homocysteine-treated endothelial cells. Am J Physiol Heart Circ Physiol 2002; 282: H2124-H2133.

19. Rodriguez-Sinovas A, Boengler K, Cabestrero A, Gres P, Morente M, Ruiz-Meana M et al. Translocation of connexin 43 to the inner mitochondrial membrane of cardiomyocytes through the heat shock protein 90-dependent TOM pathway and its importance for cardioprotection. Circ Res 2006; 99: 93-101.

20. Huang RP, Fan Y, Hossain MZ, Peng A, Zeng ZL, Boynton AL. Reversion of the neoplastic phenotype of human glioblastoma cells by connexin 43 (cx43). Cancer Res 1998; 58: 5089-5096.

21. Harada K, Nonaka T, Hamada N, Sakurai H, Hasegawa M, Funayama T et al. Heavy-ioninduced bystander killing of human lung cancer cells: role of gap junctional intercellular communication. Cancer Sci 2009; 100: 684-688.

22. Cusato K, Ripps H, Zakevicius J, Spray DC. Gap junctions remain open during cytochrome $c$-induced cell death: relationship of conductance to 'bystander' cell killing. Cell Death Differ 2006; 13: 1707-1714.

23. Frank DK, Szymkowiak B, Josifovska-Chopra O, Nakashima T, Kinnally KW. Single-cell microinjection of cytochrome $c$ can result in gap junction-mediated apoptotic cell death of bystander cells in head and neck cancer. Head Neck 2005; 27: 794-800.

24. Blanc EM, Bruce-Keller AJ, Mattson MP. Astrocytic gap junctional communication decreases neuronal vulnerability to oxidative stress-induced disruption of $\mathrm{Ca}^{2+}$ homeostasis and cell death. J Neurochem 1998; 70: 958-970.

25. Ozog MA, Siushansian R, Naus CC. Blocked gap junctional coupling increases glutamateinduced neurotoxicity in neuron-astrocyte co-cultures. J Neuropathol Exp Neurol 2002; 61: 132-141.

26. Yasui K, Kada K, Hojo M, Lee JK, Kamiya K, Toyama J et al. Cell-to-cell interaction prevents cell death in cultured neonatal rat ventricular myocytes. Cardiovasc Res 2000; 48 68-76.

27. Danesh-Meyer HV, Kerr NM, Zhang J, Eady EK, O'Carroll SJ, Nicholson LF et al. Connexin43 mimetic peptide reduces vascular leak and retinal ganglion cell death following retinal ischaemia. Brain 2012; 135(Part 2): 506-520.

28. Moorby C, Patel M. Dual functions for connexins: $\mathrm{Cx} 43$ regulates growth independently of gap junction formation. Exp Cell Res 2001; 271: 238-248.

29. Krutovskikh VA, Piccoli C, Yamasaki H. Gap junction intercellular communication propagates cell death in cancerous cells. Oncogene 2002; 21: 1989-1999.

30. Lin JH, Weigel H, Cotrina ML, Liu S, Bueno E, Hansen AJ et al. Gap-junction-mediated propagation and amplification of cell injury. Nat Neurosci 1998; 1: 494-500.

31. Cotrina ML, Kang J, Lin JH, Bueno E, Hansen TW, He L et al. Astrocytic gap junctions remain open during ischemic conditions. J Neurosci 1998; 18: 2520-2537.

32. Andrade-Rozental AF, Rozental R, Hopperstad MG, Wu JK, Vrionis FD, Spray DC. Gap junctions: the 'kiss of death' and the 'kiss of life'. Brain Res Brain Res Rev 2000; 32 : 308-315.

33. Kameritsch P, Pogoda K, Ritter A, Munzing S, Pohl U. Gap junctional communication controls the overall endothelial calcium response to vasoactive agonists. Cardiovasc Res 2012; 93: 508-515.

34. Wilson MR, Close TW, Trosko JE. Cell population dynamics (apoptosis, mitosis, and cellcell communication) during disruption of homeostasis. Exp Cell Res 2000; 254: 257-268.

35. Kameritsch $\mathrm{P}$, Khandoga N, Nagel W, Hundhausen C, Lidington D, Pohl U. Nitric oxide specifically reduces the permeability of $\mathrm{C} \times 37$-containing gap junctions to small molecules. J Cell Physiol 2005; 203: 233-242.

36. Weber PA, Chang HC, Spaeth KE, Nitsche JM, Nicholson BJ. The permeability of gap junction channels to probes of different size is dependent on connexin composition and permeant-pore affinities. Biophys J 2004; 87: 958-973.

37. Elfgang C, Eckert R, Lichtenberg-Frate H, Butterweck A, Traub O, Klein RA et al. Specific permeability and selective formation of gap junction channels in connexin-transfected HeLa cells. J Cell Biol 1995; 129: 805-817.

38. Contreras JE, Sanchez HA, Veliz LP, Bukauskas FF, Bennett MV, Saez JC. Role of connexin-based gap junction channels and hemichannels in ischemia-induced cell death in nervous tissue. Brain Res Brain Res Rev 2004; 47: 290-303.

39. Plotkin LI, Manolagas SC, Bellido T. Transduction of cell survival signals by connexin-43 hemichannels. J Biol Chem 2002; 277: 8648-8657.

40. Baroja-Mazo A, Barbera-Cremades M, Pelegrin P. The participation of plasma membrane hemichannels to purinergic signaling. Biochim Biophys Acta 2013; 1828: 79-93.

41. Neijssen J, Pang B, Neefjes J. Gap junction-mediated intercellular communication in the immune system. Prog Biophys Mol Biol 2007; 94: 207-218.

42. Foss B, Tronstad KJ, Bruserud O. Connexin-based signaling in acute myelogenous leukemia (AML). Biochim Biophys Acta 2010; 1798: 1-8.

43. Orrenius S, Zhivotovsky B, Nicotera P. Regulation of cell death: the calcium-apoptosis link Nat Rev Mol Cell Biol 2003; 4: 552-565.

44. Jiang S, Chow SC, Nicotera P, Orrenius S. Intracellular $\mathrm{Ca}^{2+}$ signals activate apoptosis in thymocytes: studies using the $\mathrm{Ca}(2+)$-ATPase inhibitor thapsigargin. Exp Cell Res 1994; 212: 84-92. 
45. Martikainen P, Kyprianou N, Tucker RW, Isaacs JT. Programmed death of nonproliferating androgen-independent prostatic cancer cells. Cancer Res 1991; 51: 4693-4700.

46. Yan J, Khanna KK, Lavin MF. Defective radiation signal transduction in ataxiatelangiectasia cells. Int J Radiat Biol 2000; 76: 1025-1035.

47. Miyamoto S, Izumi M, Hori M, Kobayashi M, Ozaki H, Karaki H et al. Xestospongin C, a selective and membrane-permeable inhibitor of $\mathrm{IP}(3)$ receptor, attenuates the positive inotropic effect of alpha-adrenergic stimulation in guinea-pig papillary muscle. Br J Pharmacol 2000; 130: 650-654.

48. Yamamoto $K$, Hashimoto $K$, Isomura $Y$, Shimohama S, Kato N. An $I P_{3}$-assisted form of $\mathrm{Ca}^{2+}$-induced $\mathrm{Ca}^{2+}$ release in neocortical neurons. NeuroReport 2000; 11: 535-539.

49. Kameritsch P, Pogoda K, Ritter A, Munzing S, Pohl U. Gap junctional communication controls the overall endothelial calcium response to vasoactive agonists. Cardiovasc Res 93: $508-515$

50. Chien MM, Zahradka KE, Newell MK, Freed JH. Fas-induced B cell apoptosis requires an increase in free cytosolic magnesium as an early event. J Biol Chem 1999; 274: 7059-7066

51. Scoltock AB, Bortner CD, St J Bird G, Putney JW Jr, Cidlowski JA. A selective requirement for elevated calcium in DNA degradation, but not early events in anti-Fas-induced apoptosis. J Biol Chem 2000; 275: 30586-30596.

52. Krysko DV, Mussche S, Leybaert L, D'Herde K. Gap junctional communication and connexin43 expression in relation to apoptotic cell death and survival of granulosa cells. $J$ Histochem Cytochem 2004; 52: 1199-1207.

53. Nodin C, Nilsson M, Blomstrand F. Gap junction blockage limits intercellular spreading of astrocytic apoptosis induced by metabolic depression. J Neurochem 2005; 94 $1111-1123$
54. Liu B, Wang Q, Yuan DD, Hong XT, Tao L. Berberine potentizes apoptosis induced by $X$-rays irradiation probably through modulation of gap junctions. Chin Med J (Engl) 2011; 124: 1221-1228.

55. Azzam El, de Toledo SM, Little JB. Direct evidence for the participation of gap junctionmediated intercellular communication in the transmission of damage signals from alphaparticle irradiated to nonirradiated cells. Proc Natl Acad Sci USA 2001; 98: 473-478.

56. Zhou H, Randers-Pehrson G, Suzuki M, Waldren CA, Hei TK. Genotoxic damage in non-irradiated cells: contribution from the bystander effect. Radiat Prot Dosimetry 2002; 99: 227-232.

57. Ripps H. Cell death in retinitis pigmentosa: gap junctions and the 'bystander' effect. Exp Eye Res 2002; 74: 327-336

58. Oyaizu N, Adachi $\mathrm{Y}$, Hashimoto F, McCloskey TW, Hosaka N, Kayagaki N et al Monocytes express Fas ligand upon CD4 cross-linking and induce CD4 + T cells apoptosis: a possible mechanism of bystander cell death in HIV infection. J Immunol 1997; 158: $2456-2463$

59. Laemmli UK. Cleavage of structural proteins during the assembly of the head of bacteriophage T4. Nature 1970; 227: 680-685.

cc) $\odot$ Cell Death and Disease is an open-access journal published by Nature Publishing Group. This work is licensed under a Creative Commons Attribution-NonCommercialNoDerivs 3.0 Unported License. To view a copy of this license, visit http://creativecommons.org/licenses/by-nc-nd/3.0/ 